\title{
Which is more important and insidious in dialysis patients? Occult Hepatitis B or Occult Hepatitis C?
}

\section{Diyaliz hastalarında hangisi daha önemli ve sinsidir? Okült Hepatit B veya Okült hepatit} C mi?

\author{
• Özlem Zanapalıoğlu Gazel, Alper Şener
}

Çanakkale Onsekiz Mart University Faculty of Medicine, Department of Infectious Disease, Çanakkale, Turkey

\section{ABSTRACT}

Objectives: The aim of this study was to investigate the presence of Occult hepatitis B infection (OBI) and Occult hepatitis C infection $(\mathrm{OCl})$ in hemodialysis patients and to determine whether there is activation in follow-up or not.

Materials and Methods: Demographic data of $100 \mathrm{HD}$ patients with normal alanine aminotransferase (ALT) levels included in the study, causes of renal failure, access to hemodialysis, duration of hemodialysis, ALT levels, hepatitis indicators were recorded. Serum antiHBc IgG was tested by ELISA (Architecht, Abbott). Serum HBV DNA, HCV RNA (in peripheral blood mononuclear cells- PBMNH) were investigated by 'real-time' polymerase chain reaction method. Results: AntiHBc IgG positivity was detected in $27 \%$ of patients, but there's no antiHBc IgG positivity alone. In $4 \%$ of the patients, HBV DNA positivity and OBI infection were detected. None of the patients showed HCV RNA positivity in serum and in PBMNH, therefore $\mathrm{OCl}$ was not detected. None of the patients developed $\mathrm{OBI}$ or $\mathrm{OCl}$ activation in a five years follow-up. Renal transplantation was performed in one of the $\mathrm{OBI}$ patients and lifelong prophylaxis was planned with oral antiviral drugs.

Conclusion: Presence of $\mathrm{OC}$ is lower than $\mathrm{OBI}$ in hemodialysis patients.

Key words: Occult Hepatitis B, occult hepatitis C, hemodialysis
öZ

Amaç: Bu çalışmanın amacı hemodiyaliz hastalarında Okült hepatit enfeksiyonu (OBE) ve Okült hepatit C enfeksiyonu (OCE) varlığını araştırmak ve izlemde aktivasyon olup olmadığını tespit etmektir.

Gereç ve Yöntemler: Çalışmaya dahil edilen normal alanin aminotransferaz (ALT) düzeylerine sahip 100 HD hastasının demografik verileri, böbrek yetmezliği nedenleri, hemodiyalize erişim, hemodiyaliz süresi, ALT düzeyi, hepatit göstergeleri kaydedildi. Serum antiHBc IgG, ELISA (Architecht, Abbott) ile test edildi. Serum HBV DNA, HCV RNA (periferik kan mononükleer hücrelerinde-PKMNH) "gerçek zamanlı" polimeraz zincir reaksiyonu yöntemi ile araştırıldı.

Bulgular: AntiHBc lgG pozitifliği hastaların 27'sinde saptandı. ancak izole antiHBc lgG pozitifliği yoktu. Hastaların\% 4'ünde HBV DNA pozitifliği ve OBE tespit edildi. Hiçbir hastada serum ve PBMNH'de HCV RNA pozitifliği yoktu, bu nedenle OCE saptanmadı. Beş ylllık takipte hiçbir hastada OBE veya OCE aktivasyonu gelişmedi. OBE hastalarından birinde böbrek nakli yapıldı ve oral antiviral ile yaşam boyu profilaksi planlandı.

Sonuç: Hemodiyaliz hastalarında OCE varlığı OBE'den düşüktür. Anahtar Kelimeler: Okült hepatit B, Okült hepatit C, hemodiyaliz

Zanapalıoğiu Gazel Ö, Şener A. Which is more important and insidious in dialysis patients? Occult Hepatitis B or Occult Hepatitis C? Viral Hepat J. 2020 


\section{Introduction}

In patients with chronic renal failure (CRF), infections are important causes of morbidity and mortality. These patients are particularly at risk of parenterally transmitted viral hepatitis (1). Hepatitis B and C viruses are primarily transmitted parenterally in dialysis patients. Chronic hepatitis $\mathrm{B}$ and $\mathrm{C}$ are more common infectious agents in patients with chronic renal failure compared to the normal population. These infections are also causes morbidity and mortality in patients with chronic renal failure and in patients undergoing renal transplantation $(2,3)$. According to the Turkish Nephrology Association; hepatitis B surface antigen ( $\mathrm{HBsAg}$ ) positivity was $2,65 \%$ and antiHCV positivity was $3,94 \%$ in hemodialysis patients in Turkey at 2017 (3).

Hepatitis B virus (HBV) infection recovery defined as $\mathrm{HbsAg}$ dissaperance with HBV DNA negativity in case of hepatitis B surface antibodies (Anti Hbs) positivity. The evaluation of serological markers for determining the infection is important but may be insufficient. Sensitive polymerase chain reaction (PCR) techniques have shown a low level of HBV DNA in some patients who have spontaneously and serologically lost their HBsAg in serum and / or liver. Therefore, this condition, which defines chronic HBV infection (by PCR) with undetectable HBsAg levels, is called occult HBV infection (OBI) (4). Occult HBV infection is divided into two groups according to antiHBc and antiHBs positivity.

The actual cause of approximately $10 \%$ of liver enzyme abnormalities is unknown. In the last decade, occult hepatitis C virus infection $(\mathrm{OCl})$ has been defined with studies have been conducted to identify patients with chronic liver disease whose etiology has not been clarified. Firstly HCV RNA was detected in liver cells when anti HCV and HCV RNA were negative in serum. Thereafter HCV RNA was found in liver and in PBIVINC with undiagnosed high liver function tests. Viral RNA can be detected in PBMNC over $70 \%$ of patients with $\mathrm{OCl}(5,6)$

$\mathrm{OCl}$ defined by Castillo et al. HCV RNA is detected in liver cells, while serum anti HCV and HCV RNA was hegative (6). In the following years, Fabrizi et al. defined $\mathrm{OCl}$, in patients with elevated liver enzyme; serum anti HCV and HCV RNA were negative, whereas HCV RNA was detected in liver cells and PBMNC (8). Recent studies report two different types of $\mathrm{OCl}$; seronegative and positive. In both types of OCI, HCV RNA is positive in liver cells of patients, and viral RNA can be detected in PBMNC with serum ultracentrifugation $(9,10)$.

The aim of this study was to investigate the presence of $\mathrm{OBI}$ and $\mathrm{OCl}$ in hemodialysis patients in Canakkale. And follow up the reactivation of $\mathrm{OB}$ and $\mathrm{OCl}$.

\section{Materials and Methods}

We included 100 patients over 18 years of age and written informed consent was obtained from the patients. Patients were selected who had normal ALT levels and shows seronegativity for HbsAg and antiHCV antibody tests. The demographic data, ALT levels, hemodialysis periods, hepatitis B vaccination history, HBsAg, antiHbs and antiHCV indicators were recorded.

Peripheral venous blood samples were collected from $5 \mathrm{ml}$ each of 3 separated biochemistry tubes for antiHBC IgG, HBV DNA, HCV RNA, and an amount of $9 \mathrm{ml}$ blood in EDTA tube for PBMNC separation.

AntiHBc lgG test was carried out with the Architect Anti - HBc II Reagent kit. Blood samples for HBV DNA and HCV RNA isolation were centrifuged at $1500 \mathrm{rpm}$ for 15 minutes. The obtained sera were stored at $-20^{\circ} \mathrm{C}$ until isolation of DNA and RNA.

Whole blood $(9 \mathrm{~mL})$ was taken into the EDTA tube for further differentiation of PBMNC. Histopaque (R)-1077 (9ML) was added to $50 \mathrm{ml}$ falcon tube. Gently drop whole blood with sterile pasteur pipette from the edge of the faicon tube onto the Histopaque @-1077. According to the manufacturer's recommendations, it was centrifuged at $400 \mathrm{G}$ cycle for 30 minutes. After centrifugation, the cells in the cloud appearing in the middle of the tube were identified as PBMNC, and these cells were taken to the microvida lid cryo tubes by taking $3 \mathrm{ml}$ with the help of micropipette. RNA was stored at $-20^{\circ} \mathrm{C}$ until isolation.

Prepared serum and PBMNCs after DNA / RNA isolation sing HBV - DNA and HCV - RNA isolation kit (Magnesia @2448 nucleic acid isolation and PCR setup robot) in Anatolia Diagnostic and Biotechnology R \& D laboratory Montaina $\AA 4896$ Real Time - PCR Bosphore® HBV / HCV quantification(analytical sensitivity is $25 \mathrm{IU} / \mathrm{ml}$ and its linear range is $1 \times 10$ duy $-1 \times 10 \vee \mathrm{IU} / \mathrm{ml}$.) was

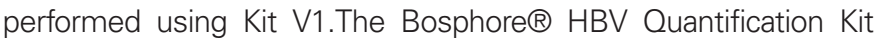
$\mathrm{V} 1$ (analytical sensitivity of $10 \mathrm{IU} / \mathrm{ml}$ and a linear range of $1 \times 10$ analytic - 1x 10 Kit IU / ml.)

$\mathrm{OBI}$ was defined as HBV DNA positivity in patients with $\mathrm{HBsAg}$ negative and with normal ALT levels.

$\mathrm{OCl}$ was defined as HCV RNA positivity in patients with antiHCV negative in patients with normal ALT levels.

\section{Results}

The study included 100 patients with normal ALT levels and HBsAg negative, antiHCV negative in one dialysis center in Canakkale province. Demographic data of the patients included in the study are given in Table 1 . Fiftyeight (58\%) of the patients

\begin{tabular}{|l|l|}
\hline \multicolumn{2}{|l|}{ Table1. General characteristics of patients } \\
\hline Age (year), \pm SD & $63.5 \pm 12,5$ \\
\hline Gender (Female/Male) & $42 / 58$ \\
\hline Comorbid diases (other than CRF) N (\%) & $88(\% 88)$ \\
\hline Hemodialysis way & $15(\% 15)$ \\
\hline Catheter N (\%) & $85(\% 85)$ \\
A/V fistula N (\%) & $67.6 \pm 51,3$ \\
\hline Total hemodialysis time (month), \pm SD & $10.5 \pm 7,2$ \\
\hline ALT, \pm SD & \\
\hline ALT: Alanine aminotransferase, normal range: $0-55$ IU/ml, AN: Arteriovenous, SD: Standart deviation \\
\hline
\end{tabular}


were male and 42 (42\%) were female. The mean age was $63.5 \pm$ 12.5 years. Eightyfive (85\%) patients underwent dialysis through arteriovenous fistula (AVF). Other patients underwent dialysis with a permanent hemodialysis catheter. The mean duration of dialysis was 67.6 months. $95 \%$ of the patients had dialysis 3 days a week and $5 \%$ had 2 days dialysis. When the serological tests of the patients are examined; 27 patients $(27 \%$ ) were showed antiHBc IgG and antiHBs positivity together. None of the patients had antiHBc IgG positivity alone. HBV DNA was positive in 4 (4/100, $4 \%$ ) of all patients. $\mathrm{OBI}$ diagnosed patients' characteristics were shown at table 2 . When the hepatitis $B$ vaccination history were examined, it was seen that 55\% had at least three doses.

There was not any clinical and laboratory activation of hepatitis $B$ in five-years follow-up of these four patients.Serum and PBCMN were investigated by polymerase chain reaction for $\mathrm{OCl}$ and $\mathrm{HCV}$ RNA was not detected in any of the patients. The general characteristics of 27 patients with antiHBc lgG positive are in Table 2. The mean age of the patients was $57 \pm 16.2$ years. The mean duration of hemodialysis was $72.7 \pm 37.5$ months. ALT levels were within normal limits and the mean was $9.7 \pm 2.3 \mathrm{lU} / \mathrm{mL}$.

\section{Discussion}

Although HBsAg positivity was decreased in hemodialysis patients, HBV viremia (OBI) was shown by PCR tests. The prevalence of $\mathrm{OBI}$ varies from $1 \%$ to $87 \%$ in different regions of the world (11).

The incidence of $\mathrm{OBI}$ is different in every country, for example it has been reported between $0 \%-36.4 \%$ in blood donors in our country (12). According to other studies, OBI was reported actullay between $3.4 \%$ and $19 \%$ in hemodialysis patients (13).

In this study, we investigated the presence of $\mathrm{OBI}^{\mathrm{B}}$ and $\mathrm{OCl}$ with real time PCR in hemodialysis patients. In our study, the incidence of $\mathrm{OBI}$ was found $4 \%$. But $\mathrm{OCl}$ was not obtained in our study group. In Egypt, Helaly et al. found antiHBc lgG positivity in all patients who had detected $\mathrm{OBI}$. Therefore, in the presence of antiHBc lgG positivity, patients should be investigated for possible OBI by molecular methods (14). But in our study none of the OBI patients did not showed this antibody positivity for core antigen. In our opinion, the main cause of this stiutaion is; core antigen production was irregular in hepatocytes. If the replication continues regularly, you can detect antibody response, but if not antibody shows negativity. In hemodialysis patients this irregular sythesis might be in maximum level because of the CRF.
In the study conducted by Fontenele et al. in Brazil, 79\% of 301 patients with CRF who had hemodialysis showed antiHBs positivity and isolated antiHBs positivity was detected in only $35 \%$ of the patients. They found $\mathrm{OBI}$ in three patients with antiHBs positivity alone (15). AntiHBs positivity was found in $95 \%$ of our patients and $68 \%$ of patients have been showed antiHBs positivity alone. All of $\mathrm{OBI}$ patients showed anti HBs positivity alone.

Although the exact cause is unknown, the presence of antiHBs in hemodialysis patients with $\mathrm{OBI}$ suggests that inadequate neutralization of virus and routine serological profiles alone are not always sufficient to define the status of HBV infection

There are also important studies on the clinical consequences of $\mathrm{OBI}$ in organ transplant patients. Each hemodialysis patient is a candidate for kidney transplantation. Before solid organ transplantation, recipients should be screened for serological tests (HBsAg, Anti-HBs, Anti-HBc lgM, IgG or total, antiHCV) for possible hepatitis. In hemodialysis patients receiving immunosuppressive therapy before and after transplantation, viral activation of HCV and HBV might have seen and also cause fulminant hepatitis. Screening with appropriate methods before solid organ transplantation will increase transplant success (16). Therefore, it is suggested that these patients should be evaluated in terms of HBV DNA search by molecular methods.

One of the OBI patient has been undergone renal transplantation. Oral antiviral prophylaxis has been began and hepatitis B viral activation hasn't seen as other $\mathrm{OBI}$ patients in five-year follow-up.

\section{Conclusion}

In conclusion, in our study, we found the incidance of OBI $4 \%$ in seronegative hemodialysis patients, but $\mathrm{OCl}$ was not obtained. When the infectious properties of these patients are also taken into consideration, it is inevitable that HBV negative patients will be infected by dialysis. It is an important risk factor that may adversely affect morbidity and mortality in these patients whose quality of life has decreased significantly due to chronic renal failure. Since our key diagnostic method for detection of OBI occult HBV infection is HBV-DNA, it is essential to standardize the technique and used method. During the follow-up in dialysis units, once a year, viral DNA analysis with PCR-based method can be helpful in preventing the problems that may occur in the expected for organ transplantation.

Table 2. 0 cult Hepatitis B diagnosed patients' characteristics

\begin{tabular}{|c|c|c|c|c|c|c|}
\hline Patient Number & Age & Gender & HD way & $\begin{array}{l}\text { Total HD time } \\
\text { (month) }\end{array}$ & $\begin{array}{l}\text { HBV-DNA level } \\
(\mathrm{IU} / \mathrm{ml})\end{array}$ & $\begin{array}{l}\text { Anti Hbs } \\
\text { titer (mIU/mL) }\end{array}$ \\
\hline (42) & 33 & $\mathrm{M}$ & AVF & 59 & 61.4 & 1000 \\
\hline (58) & 61 & $M$ & AVF & 112 & 56.9 & 270 \\
\hline (98) & 67 & $F$ & AVF & 93 & 60 & 220 \\
\hline (100) & 67 & $M$ & AVF & 27 & 48.6 & 21 \\
\hline
\end{tabular}




\section{Study Limitations}

Our study population was not enough to make a general recommendation for management of $\mathrm{OBI}$ in all dialysis patients.

\section{Acknowledgements}

This study was financially supported by the Turkish Viral Hepatitis Association. This study is presented as an oral presentation in ICC 2017 in Taipei-TAIWAN.

\section{References}

1. Aygen B.Özel hasta gruplarında infeksiyon kontrolü: hemodiyaliz hastalarında infeksiyon kontrolü. Hastane Infeksiyonları Dergisi. 2001.5: 247 - 285 .

2. Çiftçibaşı I, Örmeci A, Karaca Ç. Viral Hepatitler ve Kronik Böbrek Yetersizliği. Viral Hepatit 2013 (1.baskı).Istanbul. Viral Hepatitle Savaşım Derneği Tabak, F, Tosun S. Bölüm 35.

3. Süleymanlar G, AltıparmakMR, Seyhani N, Trabulus S. (2017). Türkiye'de Nefroloji, Diyaliz ve Transplantasyon Registry 2017. Ankara. Türk Nefroloji Derneği Yayını.

4. Ergünay K. Gizli (okült) hepatit b enfeksiyonu. Mikrobiyoloji Bülteni. 2005.39: 241 - 249

5. Barril G, Casillo I, Arenas MD, Espinosa M, Garcia- Valdesas. Occult hepatitis c virus infection among hemodialysis patients. J Am Soc Nephrol.2008. 19: 2288 - 2292.

6. Castillo I, Pardo M, Bartolome J, Ortiz -Movilla N, Rodriguez-Inıgo $E$ et all. Occult hepatitis $c$ virus infection in patients in whom the etiology of persistently abnormal results of liver-function tests is unknown. The Journal of Infectious Disease. 2004. 189: 7 - 14.
7. Ocana S, Casas ML, Bugihas I, Lledo JL. Diagnostic strategy for occult hepatitis b virus infection. World J Gastroenterol. 201117(12): 1553 - 1557.

8. Fabrizi F, Martin P. Occult hepatitis c virus infection in hemodialysis. J Am Soc Nephrol. 2008.19: 2248 - 2250.

9. Carreno V. Occult hepatitis c virus infection: a new form of hepatitis c. World J Gastroenterol. 2006.12(43): 6922 - 6925

10. Carreno V. Seronegative occult hepatitis $C$ virus infection: clinical implications. Journal of Clinical Virology.2014 . 61: 315-320.

11. Makvand M. Update on occult hepatitis $B$ virus infection. World $J$ Gastroenterol 2016 October 21; 22(39): 8720-8734

12. Afyon M, Avcı IY, Ülçay A, Diktaş H. Occult hepatit B enfeksiyonu. J Clin Anal Med. 2013.4(5): 435 - 439.

13. Kazmierczak J, Pawelczyk A Cortes KC, Radkowski M. Seronegative hepatitis $C$ virus infection. Arch. Immunol. Ther. Exp. 2014. 62:145- 151

14. Helaly GF Ghazzawi EF, Shawky SM, Farag FM. Occult hepatitis $b$ virus infection in among chronic hemodialysis patients in Alexandria, Egypt. J Infect Publıc Health. 2015. DOI: 10.1016/j. jiph.2015.04.019.

15. Fontele AMM, Gainer JB, Silva DV, Cruz-Santos MD, Salgado JV. Occult hepatitis B among patients with chronic renal failure on hemodialysis from a capital city in northeast Brazil. Hemodialysis International. 2015.19: 353 - 359.

16. Jamali R. The importance of occult hepatitis B infection screening in pre - transplant evaluation. Thrita J Med Sci. 2014.3(2):e16044. 